\title{
LEARNING FROM MISTAKES: STUDENTS' PERCEPTION TOWARDS TEACHER'S ATTITUDE IN WRITING CORRECTION
}

\author{
Pipit Muliyah $^{1}$, Agnira Rekha ${ }^{2}$, Dyah Aminatun ${ }^{3}$ \\ STAI Sufyan Tsauri Majenang ${ }^{1}$ \\ Universitas Tidar $^{2}$ \\ Universitas Teknokrat Indonesia ${ }^{3}$ \\ ${ }^{1}$ pipitmuliyahoke@gmail.com; ${ }^{2}$ agnirarekha@untidar.ac.id; ${ }^{3}$ dyah_aminatun@teknokrat.ac.id
}

\begin{abstract}
Most of writing teachers agree that writing skill is the most difficult subject for foreign language learners. The difficulties come from complexity of planning, idea organization, revision, and the use of lexical and grammatical. Correcting or giving feedback to students' writing is also difficult for teachers, since it takes time and energy. Thus, this study tried to explore students' perception towards teachers' attitude in writing correction by distributing questionnaire to 20 students and 4 writing teachers, observing the teaching activities, and documenting students' work. The study showed the result that teachers and students responses revealed various discrepancies between teachers and students' perception for error and mistake correction. Then, most of students indicated that they do not understand the teachers' feedback towards their writing composition. Accordingly, it is prescribed that teachers conduct classroom discussion on error correction, criticism, and composing in arrange to assist their understudies get it how input is aiming to influence their composing and why it is given in specific way.
\end{abstract}

Keywords: students' perception, teachers' attitude, writing correction.

\section{INTRODUCTION}

Writing is a productive skill which requires someone to transfer words or utterances, to make up correct sentences, to make letters, or symbols on a surface, and to communicate a message to a reader for a purpose systematically. Writing is one of four skills in English which is considered to be the most difficult skill to be mastered by students since they have to express their ideas in a written form to the readers with good content, grammar, vocabulary, organization, and mechanic so that the readers can get their messages correctly. Thus, teaching writing is seen to be very challenging for a teacher due to the fact that writing does not merely focus on the product of writing but also on the process of writing which requires the students to 
follow every single step in writing. The process of writing the text will influence the product of the writing. In other words, a good writing product requires a good writing process unexceptionally about teacher attitudes in giving feedback.

Providing feedback is viewed both by teachers and students as an important part in writing class. Error correction is also found as the most widely used method in giving writing feedback. It is seen that teachers need mush time allocation to spend in giving feedback. In the other hand, error correction can be the most important component that will contribute to students' success in writing (Ferris, 2013). There are some studies about various ways of providing feedback that are commonly practiced by teachers such as commentary, error identification, teacher-students conference, peer correction, and self-correction. However, the researches revealed that most teachers prefer to give the feedback in inconsistency. While students may prefer teachers to correct all errors at least to the extent that it is possible.

In error identification feedback, teachers located the students' error by their own preferences without considering whether the students will understand or not towards the feedback. Thus, this study discussed students' perception toward teachers' attitude in writing error correction. As the assumption that corrective error feedback is an imperative component of composing instruction and instructors must get ready to execute competently, carefully, and reliably in arrange to utilize its potential for progressing students' composing precision (Ferries, 2204). The problem of the investigation is "How foreign language learners "see" teachers" written error correction?". The result of the study might reveal new perspectives in teaching writing, focusing more on whether the correction given solve the students writing error or not.

\section{REVIEW OF LITERATURE}

\section{What is writing?}

Writing not only means knowing how to structure papers, what to write about, and how to express ourselves but also involves knowing what to include and leave out, who can appropriately use a particular genre with, and when it is appropriate to use the genre at all (Hyland, 2006). Composing is additionally a way of communicating a message to a peruser for a reason. At that point, composing is seen as the act of shaping letters or combination of letters in making marks on level surface of a few kind. Hence, composing is called as a profitable aptitude (Harmer, 2004). Productive skill can be characterized as creating a grouping that's organized in certain arrange and connected together in certain ways. However, writing is not an unconstrained ability or procured effectively. In fact, it is seen as likely the foremost troublesome thing to do in language (Nunan, 1999). Moreover, writing is known as a complex, cognitive process that requires maintained mental exertion over impressive period of time. Based on the theory expressed some time recently, writing may be a mental and physical act of communicating words to readers for a particular reason productively and systematically.

\section{Teaching writing competence}

People used writing in every situation. It is undeniable that we cannot live without writing. It means that writing helps us communicate, interact, and socialize with other people as same as the daily conversations. Foreign language learners need to master writing in order to maintain social relationship. Teaching writing on EFL classes is to get things done and to apply important things in our real life. The teachers can teach the students how to write diary entry, journal entry, 
letters, notes, instructions, reports, menus, essays, recipes, and stories. Teaching writing is a way of delivering messages to students, it requires our determination, patience, and perseverance when making the students understand what and how to write effectively, and the students can participate by making their own writing as the product of the learning.

In English language-teaching classroom, teacher needs to provide and enrich the students' learning experiences. The learning experiences are achieved through activities to explore the environment by having active interaction with friends and other people. Consequently, teachers must find appropriate teaching technique in order to make the students work together and create writing. Not only by implementing appropriate teaching technique, teacher also must consider the types of feedback that is given to students writing composition. It is purposed to achieve the goal of teaching writing. In the end, students are able to write properly if they got appropriate teaching technique and feedback.

\section{Mistakes in writing correction}

A mistake is perceived as something normal, something that the educator may distinguish, treat, or disregard and it is based on their choice. A mistake is not an issue of information but it is an issue of its application (Corder, 1991). It implies that errors are systematic, and mistake are not. Error can be classified concurring to fundamental sort, emissive, added substance, substitutive or related to word arrange. Making mistakes is accepted as a vital and valuable portion in language learning since it permits learners try with language and degree their mastery in writing composition. It is additionally known that errors and mistake that understudies cannot adjust without offer assistance conjointly require explanation. Here, mistake happens when understudies attempt to say something that is past their current level information or language processing. Subsequently the understudies are still preparing, they may not know or know the portion of language (Wang, 2010).

In this case, students cannot correct errors themselves because misunderstanding of what is wrong. Mistake and errors may be caused by having no prior knowledge to the rules, the structure of the language (ignorance); and the students' failure to implement what they have learned (Valero, et.al, 2008). Edge (1989) as specified at Wang (2010) separated mistakes into three sorts, slips, mistakes, and endeavors. "Slips" are mistakes that understudies can rectify by themselves; "errors" are mistakes which understudies cannot redress by themselves; "attempts" are students' eagerly of utilizing the dialect without knowing the proper way.

\section{Errors in writing correction}

Feedback is very useful in writing process. Teacher can encourage and train students by giving feedback. There are some approaches in providing error correction feedback. First, general approaches which divided in two approaches; the comprehensive (unfocused) approach which involved the teachers correct all errors in a student's text; and the particular (centered) approach targets particular linguistics highlights as it were, clearing out all other mistakes exterior of the current center space uncorrected. Besides, unequivocal error adjustment which is done where the teacher straightforwardly gives the proper frame or structures to explicitly appear the mistake within the etymology structure of the students' written content. Thirdly, verifiable

written mistake correction which has a place to sort of input where the target language teacher 
basically appears that an error has been made through different means such as encompassing, or correction codes alluding to particular syntactic errors. The final, mistake adjustment codes which includes giving codes that incorporate symbols "[]" for lost word, or "()" for additional words and shortened forms (e,g SIV- Subject Verb Understanding), to illuminate the understudies not as it were an blunder has been made, but too the kind of mistakes made (Ellis, 2009).

\section{METHOD}

The researcher obtained the investigating finding by observing the learning process. The investigated finding was moreover by interviewing with the teacher and the understudies. At that point, the researcher obtained the investigated finding from documents. The researcher observed and noted on a few imperative focuses amid the course action. The surveys too were dispersed to the members in arrange to induce the required information. This research is done in sort of survey study to investigate and describe the students' perception towards teachers' attitudes in writing correction. The data was collected by administering questionnaire to 20 students and 4 writing teachers. The questionnaire explored about students' perception on when they receive the feedback, the type of feedback given by the teacher, students preferences of type of feedback given by the teacher, focus of the feedback, and students' problems when revising papers after getting feedback.

\section{FINDINGS}

In reaction to the inquiry about address on students' perception towards writing correction, the result of their perception is displayed in Table 1.

Table 1. Students' perception on when to receive feedback

\begin{tabular}{llllc}
\hline \multicolumn{1}{c}{ Stage } & I would like to get my correction & \multicolumn{2}{c}{$\begin{array}{c}\text { Students } \\
\text { I would like to give my } \\
\text { correction }\end{array}$} \\
\cline { 2 - 5 } & Yes & No & Yes & No \\
\hline At prewriting stage & $60 \%$ & $40 \%$ & $25 \%$ & $75 \%$ \\
\hline At the drafting stage & $30 \%$ & $70 \%$ & $25 \%$ & $75 \%$ \\
\hline At the revising stage & $90 \%$ & $10 \%$ & $75 \%$ & $25 \%$ \\
\hline At the evaluation stage & $80 \%$ & $80 \%$ & $100 \%$ & 0 \\
\hline
\end{tabular}

Table 1 showed that the students preferred time to get their correction in mostly at revising feedback which is different form teachers preferred time in giving feedback to the student, it was at evaluation stage. Based on this result, teacher must reconsider their preference to give feedback to the students as they need. By doing this way, the understudies can get gigantic back for teachers through the method of composing; hence, their advance can be assessed through a number of stages instead of as it were last item. However, the table also revealed that most teacher did not give feedback in the prewriting stage, where students need guidance whether their writing understanding correct or not (Ahmadi, et.al 2012). It means that, errors are ignored in this stage. In the other hand, every stage is important for students writing composition 
improvement. Teacher mostly just put evaluation as the most appropriate time in giving feedback. Thus, this condition showed that there is distinction between teachers' on giving feedback and students' perception on getting feedback. As the reason, teacher put evaluation stage as the most appropriate time, while students need feedback in prewriting, drafting and revising stage.

Table 2. Approach of teacher written correction

\begin{tabular}{lcccc}
\hline Indicators & \multicolumn{2}{c}{$\begin{array}{c}\text { Students } \\
\text { I would like be better if } \\
\text { teacher }\end{array}$} & \multicolumn{1}{c}{$\begin{array}{c}\text { Teacher } \\
\text { I would like to }\end{array}$} \\
\cline { 2 - 5 } & Yes & No & Yes & No \\
\hline $\begin{array}{l}\text { Comprehensive } \\
\text { approach }\end{array}$ & $80 \%$ & $20 \%$ & $25 \%$ & $75 \%$ \\
\hline $\begin{array}{l}\text { Selective } \\
\text { approach }\end{array}$ & $90 \%$ & $10 \%$ & $75 \%$ & $25 \%$ \\
\hline $\begin{array}{l}\text { Explicit } \\
\text { correction }\end{array}$ & $60 \%$ & $40 \%$ & $25 \%$ & $75 \%$ \\
\hline $\begin{array}{l}\text { Implicit } \\
\text { correction }\end{array}$ & $40 \%$ & $60 \%$ & $75 \%$ & $25 \%$ \\
\hline Codes correction & $20 \%$ & $80 \%$ & $50 \%$ & $50 \%$ \\
\hline
\end{tabular}

Related to the amount of providing feedback, the students were asked to define approach of feedback they needed. The result indicated the teachers' preferences is not in line with the students want that they wanted to have all errors are corrected (comprehensive approach) but most of students also wanted to get correction in selective approach which means that just need to revise some errors. In any case, not at all like their understudies, the larger part of teachers are not in favor of redressing all mistakes. As the reason that redressing all the errors for understudies may lead to the terrible effect on the students' self-awareness as they as it were replicated what have been rectified by teachers into the modern paper (Katayama, 2007). Teacher also assumed that by giving implicit correction will make the students to think critically of the error and become aware of these types of errors. While students preferred to have comprehensive and selective approach because this approach make them easily to identify the meaning or the error and avoiding misleading and misunderstanding. Again, it was not surprising that there is another mismatch between teachers and students' preference for error correction. Students may fail to interpret teachers' correction and sometime they ignore it. It is hence, recommended that teachers ought to clarify their reacting to their understudies.

Table 3. Focus on feedback

\begin{tabular}{|c|c|c|c|c|}
\hline \multirow[t]{2}{*}{ Indicators } & \multicolumn{2}{|c|}{$\begin{array}{c}\text { Students } \\
\text { Which aspect would like to get } \\
\text { comments to? }\end{array}$} & \multicolumn{2}{|c|}{$\begin{array}{c}\text { Teacher } \\
\text { In which aspect would you like to } \\
\text { give comment to? }\end{array}$} \\
\hline & Yes & No & Yes & No \\
\hline Grammar & $90 \%$ & $10 \%$ & $100 \%$ & 0 \\
\hline
\end{tabular}




\begin{tabular}{lllll}
\hline Mechanic & $60 \%$ & $40 \%$ & $75 \%$ & $25 \%$ \\
\hline Vocabulary & $70 \%$ & $30 \%$ & $75 \%$ & $25 \%$ \\
\hline Content & $50 \%$ & $50 \%$ & $50 \%$ & $50 \%$ \\
\hline Organization & $40 \%$ & $60 \%$ & $50 \%$ & $50 \%$ \\
\hline
\end{tabular}

In with respect to the viewpoints in writing understudies would incline toward their teacher comment to center on, it was discernible that both teachers and students appeared to desire to urge all their issues commented on by the teachers. In spite of the fact that students by and large need their error corrected, they moreover have recognition in terms of how much accentuation each error sort ought to draw in. The majority of the students accept that error relating to linguistic ought to get the most elevated consideration for redress. Language structure was still required input since a few sorts of language structure were considered difficult to overcome like run on or the part. In this case, it seems that teachers and students have the same view but in other aspects are also important to be corrected as they are united aspects (Ferries, 2003).

Table 4. Students' problems when revising after getting feedback

\begin{tabular}{ll}
\hline \multicolumn{1}{c}{ Statement } & Numbers \\
\hline I have no any problems in revising my task after the feedback & $40 \%$ \\
\hline I cannot revise all the grammatical and mechanic that teacher gave & $30 \%$ \\
\hline I am worrying new mistakes making & $50 \%$ \\
\hline I do not comprehend the teacher's written feedback & $60 \%$ \\
\hline I have no sufficient time to revise the draft & $20 \%$ \\
\hline I have too many mistakes to revise & $30 \%$ \\
\hline The teacher's written feedback is not helpful & $70 \%$ \\
\hline I do not know how to revise my task & $10 \%$ \\
\hline
\end{tabular}

Table 4 shows that one of the biggest troubles when students attempt to change the paper was that the students did not get it with the teachers' criticism. Once more, the failure in reexamining the substance and the expressions proposed by educator and I rectifying all syntactic and technician mistakes were the issues students confronted when reexamining the paper. In any case, students expected that the need of time and the hazy pointed mistakes are the reason for not being able to change it.

Table 5. Students' Satisfaction on teachers' feedback

\begin{tabular}{lll}
$\frac{\text { Students' satisfaction }}{\text { Satisfied }}$ & Number \\
\cline { 1 - 2 } Not satisfied & $\underline{9}$
\end{tabular}

The pointer of student's feeling was chosen into two parts. The primary was around the students' fulfillment in tolerating the teacher's feedback. The moment was approximately the students' feeling when their works were given input by the teacher. This finding discussed around the students' fulfillment towards teacher's remedial input in writing course. Based on the survey, a few sources tell that they were fulfilled with the way of the instructor when giving feedback. Even most of students satisfied to the teachers' feedback, teachers must consider that 
from 20 students almost a half of the students are not satisfied to the teachers' feedback, so teacher must consider and analyze it. One of the reason of dissatisfaction is that the students sometimes felt so shy and guilty when they got feedback directly in front of their friends.

Table 6. Students' preferences on direct or indirect feedback

\begin{tabular}{ll}
\hline \multicolumn{1}{c}{ Types } & Number \\
\hline Direct & 14 \\
\hline Indirect & 6 \\
\hline
\end{tabular}

It is seen that the students preferred to have direct feedback rather than indirect feedback. On the written feedback teacher can allow coordinate or roundabout remedial input. Teachers can give direct or indirect remedial feedback (Ellis, 2009). The primary includes the teacher recognizing etymological mistakes and providing students with the right frame. Moreover, direct feedback is more compelling than indirect feedback. It gives clear and concrete recommendations, the combination of the two was way better. Indirect feedback, on the other hand, presents students with a sign that an error has been made, but requires the students to selfcorrection. Indirect feedback may be a circumstance in which instructors demonstrate that errors have been made but do not give redresses. Indirect feedback involves demonstrating that an error exists by showing and finding the mistakes within the content utilizing procedures such as underlining or circling within the edge that an mistake has been made in that line of the content.

\section{FINDINGS AND DISCUSSION}

Based on the findings above, the researcher would like to analyze approximately the way of the educator gives composing correction in learning composing aptitude. Writing is a critical ability utilized to bolster other abilities in language learning. Writing ability is perceived to be exceptionally critical to make a difference students to realize scholarly success in which their writings are utilized as prove of learning like in notes and rundowns. From the findings above, it uncovered that the way the teacher gives corrective feedback influences the students' states of mind in learning writing. Ferris (1999) states feedback is advantageous for understudies to make strides the quality of their composing. It is genuine since it can make strides the quality of student's composing, centering on linguistic use, lexis, and substance. So, it can progress the students' writing generation and precision. By giving feedback, students can show the mistakes so that the students can rectify them, typically ordinarily done by giving comprehensive or specific correction to center on students' mistake.

Feedback or writing correction on composing can be chosen as a implies of making a difference students to create modification and move forward their writing aptitudes. At that point, feedback is known as any data around current behavior that can be utilized to move forward long term execution of the understudies. From that definition, it can be concluded that feedback is imperative for students to progress their execution from what they have learnt. Feedback gives clear back for creating linguistic accuracy in written compositions (Ashwell, 2000). Since it can make strides the students' writing exactness. Feedback on composing can be chosen as a implies of making a difference understudies to form modification and progress their writing aptitudes.

Teacher can provide feedback within the shape of address to inquire for clarification or recommend extension (Berzseny, 2001). Other than, teacher may provide comments which uncover understanding towards students' composition, distinguish mechanical issue in a particular sentence and grant laud when students are working well in their composing. The students felt bliss after they obtain laud from their teacher. The moderation procedures connected in teacher's feedback make an indirectness which frequently causes errors for the students 
whereas attempting to comprehend them (Hyland and Hyland, 2001). So, when misconception of the correctives feedback given it can make the students misplaced their inspiration to compose again.

\section{CONCLUSION}

Writing skill is very important in life, not only in educational life, but also in people's life. Writing skill is a way where students can express their feeling, thought, and idea. The questionnaire showed that writing in English seems to be a matter of complex issue. To acquire it, students should understand well several aspects namely content, grammar, vocabulary, mechanic, and organization. These components affect the students' writing skill as writing is matter of habit. It needs long time and more practices for students to be good writers. Another thing that must be mastered by the students is understanding teacher's feedback. Most of students want to have feedback in prewriting stage as they want to get guidance of their writing composition from the beginning. In contrast, teachers just want to put feedback on the evaluation stage even it is still good for students but there will be misunderstanding of the writing concept. Then, related to types of feedback, the students prefer to have comprehensive feedback as they will know what are they mistakes. In the other hand, teacher see comprehensive correction is not appropriate for students since it will not make the students think critically and just rewrite based on the corrections. The last is about students' perception towards focus on feedback. In this case, teachers and students have the same view that they focus on grammatical errors but actually students also need correction in the other aspects as they need to know their mistakes. Students mostly do not understand teachers written correction since they assumed that they most teachers do not give written correction as they need. Therefore, it is recommended that teachers incorporate classroom discussion on error correction, feedback, and writing in order to help their students understand how feedback is intended to affect their writing and why it is given in particular way and improve their writing skill. It can be concluded that the feedback from the teacher helped the students to organize their idea based on the correct structure and improve their ability skills. Therefore, the way of the teacher gave corrective feedback it is important to the student's in writing process. So, that feedback is essential and has a positive effect on student's writing process. When the students had positive attitude they would read and revised their mistakes, open the dictionary, and they would not repeat their mistakes again in the future. Students need some guidance in recognizing deviant forms and structure in their work. Then praise from the teacher made the students did not lose their motivation when received correctives feedback from the teacher.

\section{REFERENCES}

Ashwell, T. (2000). Patterns of teacher response to student writing in a multiple draft composition classroom: Is content feed- back followed by form feedback the best method? Journal of Second Language Writing. 9(3): 227-257.

Dixon, N. (2005). Why put writing last? - Integrating the Productive Skills in General English Classes. Paper presented in LIA International Conference 2005, Jakarta, March 22-24.

Ferris, D., \& Roberts, B. (2001). Error feedback in L2 writing classes: How explicit does it need to be? Journal of Second Language Writing, 10(3), 161-184.

Ferris, D.R. (2003). Response To Students Writing: Implications For Second Language. Fredrickson. (2013). Advances in Experimental Social Psychology. Burlington: Academic Press. 
Furnborough, C., \& Truman, M. (2009). Adult beginner distance language learner perceptions and use of assignment feedback, Distance Education, 30, 399-418

Ghaith, G. (2002).Writing. Online from http://712educators about.Com/cs/writingessays/a/paragraphs.htm. access on November, 012015 in 11.30 a.m.

Grenville, K. (2001). Writing from Start to Finish: A Six-Step Guide. Sidney: Griffin Press.

Hamouda, A. (2011). A Study of students and teachers' preferences and attitudes towards correction of classroom written errors in Saudi EFL Context. English Language Teaching. 4(3) 130-141. Doi: 10.5539/Elt.Vn4p128

Harmer, J. (2004). How to Teach Writing. Kuala Lumpur: Pearson Education Limited.

Hyland, K. 2006. Feedback in Second Language Writing. New York: Cambridge

John, B., Staurt, Y., \& Denise (2005). The effect of different types of corrective feedback on esl student writing. Journal of Second Language Writing, 14(2005), 191-205.

Kurniali, S. (2008). Tip-Trik Pilihan Blogger. Jakarta. PT Elex Media Computindo.

Lewis M. (2002). Giving Feedback in Language Classes. The University of Auckland: SEAMO Regional Language Centre

Lumetta, H., \& Jennie. 2005. Feedback for Learners: Effective Techniques and Strategies. Illinois: University of Illinois.

Nunan, D. (2003). Practical English Language Teaching. Boston: Mc Graw Hill

Pickens, Jeffrey. (2005). Perceptions and Attitudes of Individuals. New York: Jones and Barlet Publishing

Riyani, T. (2009).Improving the Students' Writing Skill through Feedback. Unpublished S-1 Thesis: Universitas Negeri Sebelas Maret.

Singh, M. \& Singh. 2002. Art of Effective English Writing. India: Chand and Company Ltd. Valero, Amando Lopez., Fernadez,Eduardo, Encabo., Iseni, Arburirm. 2008. Teachers' Attitudes Towards Coreecting Students Written Errors And Mistakes. Porta Linguarium 2(1), 21-30. doi: 1697.7467.913.

Wang, P. (2010). Dealing with English major's written errors Chinese Universities. Journal of Language Teaching And Research. 1(3), 194-205. Doi: 11.5549/Elt.Y5n3p174 